\title{
Gender Roles, Implications for Water, Land, and Food Security in a Changing Climate: A Systematic Review
}

\author{
Henry Bikwibili Tantoh ${ }^{1,2 *}$, Tracey T. J. M. McKay ${ }^{1}$, Felix Ekwabena Donkor ${ }^{1}$ and \\ Mulala Danny Simatele ${ }^{3}$
}

${ }^{1}$ Department of Environmental Science, University of South Africa, Pretoria, South Africa, ${ }^{2}$ Department of Geography, The University of Bamenda, Bambili, Cameroon, ${ }^{3}$ Global Change Institute (GCl), University of the Witwatersrand, Johannesburg, South Africa

OPEN ACCESS

Edited by:

Tapan Kumar Nath

University of Nottingham Malaysia

Campus, Malaysia

Reviewed by:

Elias Danyi Kuusaana University for Development

Studies, Ghana

Viswanathan Pozhamkandath Karthiayani,

Amrita Vishwa Vidyapeetham, Kochi

Campus, India

*Correspondence: Henry Bikwibili Tantoh

bikwibilith@gmail.com

Specialty section:

This article was submitted to Land, Livelihoods and Food Security, a section of the journal

Frontiers in Sustainable Food Systems

Received: 10 May 2021

Accepted: 29 June 2021

Published: 29 July 2021

Citation:

Tantoh HB, McKay TTJM, Donkor FE and Simatele MD (2021) Gender

Roles, Implications for Water, Land and Food Security in a Changing Climate: A Systematic Review. Front. Sustain. Food Syst. 5:707835. doi: 10.3389/fsufs. 2021.707835
Water and land are vital resources essential to ensuring sustainable and productive rural economies. They are also essential for safeguarding food security and socio-economic development. In spite of this, the concept of water-land-food (WLF) security nexus has generally been examined from a top-down manner with women mostly disenfranchised in the access and management of water and land in particular. Concurrently, risks linked with climate crisis aggravate gender inequalities. The limited access to resources, restricted formal rights through top-down management exacerbates the vulnerability of poor rural women. Furthermore, policy development procedures follow a sectoral approach with no account of interrelationship and interdependence between the sectors. This, directly and indirectly limits the stewardship of natural resources and mitigation of the effects of climate change. This study, therefore, examines gender roles and their implications for water, land, and food security in a changing climate through an integrative systematic review of literature in Sub-Saharan Africa. It further explains the importance to consider the nexus in adaptation. Food security and sustainable livelihoods could be ensured if women can freely and adequately access land and participate in decision-making processes.

Keywords: gender roles, climate change, water-land-food security, top-down management, sub-Saharan Africa

\section{INTRODUCTION}

The demand for water and land continue to increase due to rising demands from a growing population, rising urbanization, changes in consumption, and land-use patterns and since these resources are considered interconnected, there is a dire need for effective stewardship of these resources to ensure food security. It is argued that the water-land-food security (WLF) nexus is among the three paramount risks to the global economy (World Economic Forum, 2011). This is because water and land are indispensable resources required to ensuring food security. They are also essential for socio-economic development (UNDP, 2010; Tantoh and Simatele, 2018). Thus, the synergy amongst components of the WLF plays an essential role in the outcomes of rural livelihoods (Villamor et al., 2018). However, this has been jeopardized by the effects of climate change which is mostly felt on the water resource and has a significant impact on the functioning of ecosystems and human well-being. Furthermore, the effects of climate change on nature and people are mostly experienced in developing countries where a majority of the rural poor reside. In 
spite of this, the WLF nexus notion continues to be examined from a top-down approach with women mostly disenfranchised in the access and management of water and land in particular (Fonjong, 2008; Villamor et al., 2018; Tantoh and McKay, 2020), coupled with isolated sectoral approaches of policy intervention development. Likewise, risks linked with climate crisis appear to consolidate gender disparities. Climate crisis refers to environmental phenomena such as global warming, climate change that their effects. In the context of this paper, climate crisis and climate change will be used interchangeably.

Gender issues and climate change are cross-cutting priorities for many national governments. The importance of gender approach and gender mainstreaming in natural resource management has been identified as one of the most contemporary ecological problems in the developing world (Fonjong, 2008). The concept of gender mainstreaming generally refers to the process of assessing the participation of different genders (women and men) in actions comprising planning, policy, legislation at every level of a project (UN ECOSOC, 1997). It considers the values and diversities of men and women as a fundamental element of the planning and management of projects in any socio-economic and political space so that equality is perpetuated for all (UN ECOSOC, 1997). However, a gendered analysis of natural resource management problems in Sub-Saharan Africa (SSA), for example, illustrates that both women and men have distinct roles and interests in the use and management of natural resources (Fonjong, 2008). Women and the girl child, for example, are traditionally responsible for water portage exercises, the search for fuelwood and other household chores in most of SSA (Tantoh and McKay, 2018, 2020) which has limited them from excelling in other socio-economic and political spheres of the society. This is further reinforced by the patriarchal culture, leadership, decision-making, and resource management which traditionally lies in the hands of the village chief, village notables' older men, and male household heads (Tantoh and McKay, 2020). In these circumstances, women and younger people are habitually ignored, or deliberately excluded (Lendevlo et al., 2012). Consequently, local decisionmaking and control over resources reside with male members of society, re-enforcing inequality, and propagating the suppression of individual rights. This is further aggravated by inadequate political will and commitment by both the central government and the local authorities to challenge patriarchal norms and privilege at the local level, such as prejudiced gendered community obligations (Moyo, 2014; Chant, 2016; Tantoh and McKay, 2020).

In a bit to ensure gender balance, international organizations such as the United Nations Development Programme, have been mandated with a double dictate for enhancing gender equality: women's empowerment and gender mainstreaming to give women a chance especially in aspects that concern their own development (UNDP, 2008; Lendevlo et al., 2012). This is because local decision-making and control over resources mostly reside with male members of the community, nurturing inequality, and the dominance of individual rights (Tantoh and McKay, 2020). Restricting the role of women to that of their customarily defined roles hinders them from effectively achieving their rights as citizens, from improving their socioeconomic status and the development of their communities. The uneven distribution of power and responsibilities hinders the improvement of livelihoods options (Moyo, 2014). It should, however, be noted that these inequalities between gender roles and their approach to natural resource use and management have been culturally constructed.

Several studies have documented that Africa is among the most susceptible continents to climate crisis (Ebhuoma et al., 2019; Donkor et al., 2020). The Intergovernmental Panel on Climate Change (IPCC, 2008), for example, highlighted that the climate crisis is likely to have wide-ranging effects on the social order and the environment. Further evidence suggests that climate crisis is not just felt in relation to increasing temperatures, but also in respect of agriculture and the availability of water resources (Donkor et al., 2020). Land tenure security is also a challenge for women and this inhibit their empowerment.

Land tenure, for example, is complicated for most rural women due to a lack of access and proprietorship. It is argued that land tenure is often saturated with barriers such as biased cultural dynamics which exclude women from possessing, managing, and participate in decision-making processes coupled with passive legal systems (Namubiru-Mwaura, 2014). These discriminatory practices affect their wellbeing and development. Furthermore, the prevailing culture of unequal access to property has a disproportionately greater adverse impact on women from sustaining their socio-economic wellbeing (Hedditch and Manuel, 2010; Namubiru-Mwaura, 2014). One possible implication of the lack of access and control of natural resources by women, particularly land is the prevalence of poverty which further marginalizes them and reinforce gender inequality. This has, however, been constrained by sectoral policy reform and development programmes on the WLF nexus which do not give adequate attention to these realities. As a consequence, food security is affected coupled with the effects of climate change (UNDP, 2010; Chang, 2016). Although existing research recognizes the necessity of combined action to support vulnerable communities in developing countries, in particular, to adapt to climate change (Donkor et al., 2020), existing programmes are mostly directed to the national level while gender issues in vulnerable communities at the local level are neglected (Fonjong, 2008; UNDP, 2010). It is possible that the WLF nexus has not been able to effectively address the competing needs of resource users to enable development and adaptation. However, mitigation and adaptation strategies are mostly directed to sectoral goals with inadequate consideration and organization among important sectors like water and land (Biggs et al., 2015). In addition, top-down adaptation approaches have failed to solve specific interests and needs of poor women in vulnerable communities and this prevents them from effectively participating in the projects that enhance their development and that of the community (UNDP, 2010; Lendevlo et al., 2012; Chant, 2016; Tantoh and McKay, 2018). This paper sought to analyse the importance of gender roles and their implications for water, land, and food security in a changing climate in Sub-Saharan Africa through an integrative systematic review of the literature. The findings of this investigation complement 
those of earlier studies and extend the knowledge on the gender implication on the WLF food security nexus. Thereafter, the WLF Security Nexus and issues of gender implications were unpacked. This was followed by the research methodology, results, and discussions.

\section{WATER-LAND-FOOD SECURITY NEXUS; A LITERATURE REVIEW}

Previous studies have reported that WLF are indispensable components for the social, economic, and sustainable development of nations (Ringler et al., 2013; Biggs et al., 2015; Rasul and Sharma, 2016). The nexus concept reflects the diverse elements of WLF equally and identifies the connection of and uses of different resource for sustainability. According to Villamor et al. (2018), the WLF nexus concept is an extensively acknowledged analytical method with the potentials to achieve sustainable development goals. Recent development in the literature has focused on the climate crisis and the WLF nexus even though the land is rarely included and the connection between them is inadequately explored. Despite this, however, the increasing demands for freshwater, energy, and food are projected to increase in the next decade due to rising population, increasing mobility, urbanization, economic development, changes in consumption patterns, changes in technology, and climate change (Hoff, 2011). Furthermore, the WLF nexus has been mostly analyzed from a top-down approach (Villamor et al., 2018). Top-down approaches to management are full of inadequacies and time-consuming (Tantoh et al., 2019). The WLF nexus is further established in comprehensive arguments on sustainable development with aim of alleviating poverty, reducing food insecurity, and effectively manage the environment as part of the Food and Agricultural Organisation's agenda (Food and Agricultural Organisation (FAO), 2013). This has been compounded by the climate crisis, especially in rural communities in the developing world where complex challenges, such as food insecurity, the prevalence of poverty, and increasing demands of natural resources are experienced. This calls for coordinated cost-effective adaptation strategies to climate change to reduce trade-offs (Rasul and Sharma, 2016).

Given that agriculture is the highest consumer of freshwater, accounting for about $70 \%$ of global freshwater withdrawal and is central to the entire agri-food supply chain used for the production and transportation of energy, it should be judiciously managed for sustainable outcomes (FAO, 2011). Similarly, the different processes of food production consume about $30 \%$ of total global energy (FAO, 2011). However, as in many developing countries such as those in SSA, the policy processes do not adequately consider the interrelationship between water, land, and food sectors. While there is increasing advances in the WEF concept, inadequate effort, and means are available to comprehend the connections between these sectors (water, land, and food security) and the possible adaptation strategies to the climate crisis (Rasul and Sharma, 2016). Countries, communities, industries, and factories increasingly use more water and energy resulting in environmental degradation. The possibility that the situation will change is imminent as the demand for water will increase to sustain the increasing global population by 2050 . Global energy consumption is also expected to increase by $50 \%$ by 2035 (IEA 2010), while universal water extraction for irrigation purposes is expected to also increase by 105 by 2050 (FAO, 2011). These increasing demands for water and energy will result in competition, overexploitation with unpredictable impacts on the environment.

Several studies have identified that the Water, Land, Energy, and Food Security (WLEF) nexus is among the three ultimate dangers to the global economy (World Economic Forum, 2011; Rasul and Sharma, 2016). The WLEF nexus is further considered a "security nexus" because they are indispensable in socioeconomic development. Water, for example, is used to generate energy, land is used to cultivate food, and energy is required to produce, transport, and distribute water and food. The WLEF Nexus rationale, has, therefore, been conceived to promote the interrelation between the use of these resources for the wellbeing of humanity and the environment (Lawford et al., 2013). Water, Land, Energy, and Food Security nexus involves the complex interaction of water, land, and food. The interaction between water and food is well-documented (FAO, 2011, 2014; World Economic Forum, 2011; Biggs et al., 2015). Although the WLEF concept has gained a reputation in recent years, how to apply this concept to guarantee WLEF security is yet to be fully understood. It is possible that land has not been adequately considered in the nexus approach. The increasing demand for food, land, and water have been further reinforced by changes in land-use patterns in most rural communities (Rasul and Sharma, 2016). Another challenge is that the WLF nexus does not adequately enhance the prevailing integrated approaches to resources management articulated by the Integrated Water Resource Management (IWRM) (FAO, 2014). However, there is a risk of concentrating on water-related development goals at the detriment of other resources such as land which intensifies conventional sectoral approaches (FAO, 2014).

The growing pressure on natural resources has, therefore, motivated the discourse on water, land, and food security. This is because of the increasing pressure on water on the one hand while other resources are static and/or decreasing in several cases on the other (State of the Planet Declaration, 2012). Although the nexus framework has been presented from a securities viewpoint (World Economic Forum, 2011), successive forms have taken on several aspects with alternative components. For example, water resource as an indispensable component (Hoff, 2011; Abulibdeh et al., 2019), land, water, energy (Howells et al., 2013), and food as a basic element with land-water-energy relationships (Ringler et al., 2013). Many scholars have, however, examined the connection between gender, water, land, and food security in the context of climate change (Garmer, 2010; Hedditch and Manuel, 2010; Howells et al., 2013; FAO, 2014). This is because of the composite and active interactions between water, land, and food security (Biggs et al., 2015; Rasul and Sharma, 2016), which cannot be looked at in isolation from one another especially with the effect of climate change [Food and Agricultural Organisation (FAO, 2014)]. 


\section{Gender Implications in Water-Land-Food Security in a Changing Climate}

The results of climate change are widely documented. It is argued that the impacts of climate change are among the crucial tests confronting the world and especially developing countries (AfDB, 2011). The effects of climate change and the strategies proposed by various local, national, and international bodies to address climate change (mitigation and adaptation) have several implications for the economy, society, and natural environment (The Intergovernmental Panel on Climate Change (IPCC), 2018). This is because climate change occurs in combination with many other pressures on livelihoods including populations growth, increasing urbanization, economic liberalization, changes in land-use patterns among others (UNDP, 2010). According to the International Labour Organisation (ILO, 2018), for example, global extreme weather events are already affecting socioeconomic relations in many areas while water, land, and energy sectors are transforming the lifecycles of men and woman of which handicapped women are disproportionately affected.

Existing studies show the relevance of a gender approach and the role in environmental management (Lendevlo et al., 2012; Moyo, 2014; Tantoh and McKay, 2018). It is argued that women adopt and play multidimensional roles in natural resource management (Tiondi, 2000). They are essential in in environmental conservation and can contribute toward environmental conservation (Nzomo, 1992). However, recent studies show that women and men have specific functions, interests, and approaches related to water, land, energy, food security among others (Fonjong, 2008; UNDP, 2010). Gender should, therefore, be considered in crafting regulations, programmes, and approaches for sustainable outcomes. However, this is not always evident especially with recognition of gender roles and differences since government development interventions are usually unrealistic and policymakers are full of empty talks (Fonjong, 2008). Furthermore, gender roles are usually undervalued and overlooked (Tiondi, 2000). This unrecognition renders them invisible and diminish their contribution as active agents in development. In the same vein, cultural norms, and traditional practices seldom consider the significant contributions of women in the management of natural resources such as water, forests, and food production (see also Moyo, 2014; Namubiru-Mwaura, 2014; Tantoh and McKay, 2018). Furthermore, increasing gender inequality has been intensified by rising poverty and diverse governance approaches to the use and management of environmental resources (IPCC, 2014). Noteworthy is that the poor, the bulk of whom are women are expected to experience the impacts of climate change and environmental degradation most severely (Nzomo, 1992; Villamor et al., 2018). Worse of all, women are especially vulnerable not only because of their natural weakness but instead because of the socio-culturally fabricated roles attributed to them (Fonjong, 2008; UNDP, 2010; Tantoh and McKay, 2018). One of the fundamental line of reasoning to this paper is that the relation of rural women to the natural environment can apprise feminist theory and broader policy frameworks (Tiondi, 2000). Their knowledge and experiences can and should be fundamental in devising programs for sustainable development.
In view of the magnitude of gender imbalance, particularly in rural communities of developing countries, the effects of climate change are expected to increase.

\section{Gender, Water-Land-Food Security Nexus in a Sub-Saharan Africa Context}

In many poor communities such as in SSA, women do not have adequate access to key resources like land, credit facilities, livestock, tools, and technology. This has greatly limited them from showcasing their abilities in improving their livelihoods and the development of their communities. Furthermore, they are seldom involved in decision-making in natural resource management (Michael, 1998; Tantoh and McKay, 2020). It is argued that secure and resilient communities can be assured if women are considered in land tenure security which will empower them to explore other livelihood strategies (NamubiruMwaura, 2014). This is because the land is a store of value and the possession of land and property by women can enable them to engage in other socio-economic and incomegenerating endeavors (Villamor et al., 2018). Noteworthy is that women's access to land in SSA, for example, can be gained either through the state, family, or the market and since most women do not have the means to acquire land, they are economically incapacitated. Even when women have access to land, it is inadequate and restricted, preventing them from deciding the management (Namubiru-Mwaura, 2014). In most cases, however, possession and control of the land are restricted by cultural norms and tradition. Land tenure for most rural women is further complicated by daily realities such as discriminatory social dynamics, indifferent legal systems, inadequate economic prospects, and exclusion in decisionmaking (Namubiru-Mwaura, 2014; Villamor et al., 2018). This is, however, peculiar in communities with patrilineal cultures. Gender neglect in land and other natural resources has, therefore, resulted in a prolonged struggle between resource users and managers (Fonjong, 2008). Inadequate access and secure possession are repeatedly accentuated as one of the major causes of the vulnerability of women (Agarwal, 2003). However, most policy amendment disregard natural resource development and management intervention programmes which reinforce insecurities in land tenure and the vulnerability of poor rural women. If adequate policy interventions could target those at the bottom and the underprivileged, the significance and implication of gender to WLF nexus dynamics would be considered (Quisumbing et al., 2015).

This is particularly paradoxical, considering the central role of women in agriculture. Women in SSA countries, for example, are responsible for procuring fuelwood for heating and cooking and also provide potable water for domestic use (Tantoh and McKay, 2018). They are dependent on natural resources for their livelihood and wellbeing. Even though they are the principal consumers of natural resources; they are seldom involved in the management and the most vulnerable to the climate crisis. Studies show that the anticipated impacts of the climate crisis will adversely affect the accessibility of water, fisheries, forests resources which might possibly upset the growth of basic 
crops (Villamor et al., 2018). When women are empowered, necessary explicit affirmative actions are ensued (UNDP, 2010). This is because gender equity and participation in decisionmaking processes in land tenure can contribute to effective natural resource management, achieve food security, enhance rural livelihoods, and inclusive development. This, particularly, entails gender mainstreaming (UNDP, 2010). Since the WLF nexus dynamics are interrelated, the outcomes should, however, be valued by the poor to avoid conflicts because they depend on natural resources for their livelihoods and wellbeing (Ringler et al., 2013). Unfortunately, in SSA, access to natural resources by the poor remains an institutional, policy, and practical challenge for most developing countries. The unequal access to basic natural resources is, therefore, prevalent among poor rural women (Villamor et al., 2018). Worse is that there seems to be inadequate will and political promise by the central government to challenge the marginalization of women in the access and management of natural resources (Chant, 2016). The proper gender dimension is, therefore, required to offer a susceptible justification of the extent to which daily routines and experiences influence the WLF nexus issuances.

\section{Policy Implications to Access and Ownership of Land}

The present land tenure systems applied in sub-Saharan Africa is somehow related to the composite history of colonization which had profound implications (Njoh, 2013; Kenjio, 2020). A typical example is the case of Cameroon that was colonized by three European colonial powers namely, Germany, Britain, and France with diverse systems of governance (Njoh, 2013). However, social, political, and environmental transformations have necessitated land policy reforms in most of SSA. Land policy reforms are, therefore, of central importance to the land tenure system. This is especially true with calls from non-governmental organizations and development agencies, advocating the empowerment of women. Studies reveal that access to land and the ability to effectively use the land is crucial to rural livelihoods and welfare (Fonjong, 2008; Moyo, 2014; Namubiru-Mwaura, 2014). Given that land is a fundamental asset for both the rural and urban poor, particularly women, land reforms are, therefore, fundamental to poverty alleviation, improved livelihoods, and sustainable development. International tendencies in land policies advocate for a customary tenure system to achieve equitable land management, reduce land conflicts, alleviate poverty, and improve rural livelihoods (Toulmin and Quan, 2000; Cotula, 2007; Ubink and Quan, 2008).

Recent developments in the field of governance and development have led to a renewed interest in customary law and concerns on proprietorship and access to land. This has reinforced the law of governance which has become fundamental to non-governmental Organizations, international development organizations, and national governments (Ubink, 2008). Given that reforms in land administration and governance require financial, managerial, and technical proficiencies, building a legal and governance system is crucial. For example, in countries where the land transactions have been monetized, land has become scarce, and this has raised a series of concerns regarding equity of customary systems (Toulmin and Quan, 2000; Cotula, 2007). Furthermore, inadequate attention is given to the functionality of institutions, policies, laws, and stakeholders in their diverse socio-cultural and political settings (Ubink, 2008). In most instances, inadequacies in accountability, transparency, and stakeholder representation are critical (Toulmin and Quan, 2000). These developments have resulted in efforts to redefine tenure, ownership, and contestations of rights to land (Ubink and Quan, 2008). This has concentrated the control, management, and benefits of economic benefits arising from land in the hands of the state, traditional chiefs, creating tensions in several communities. It is imperative to separate the powers to allocate land and proprietorship so that the land rights of ordinary people are not forfeited to prevailing private interests.

\section{METHODOLOGY}

This desk study sought to examine obtainable literature on gender roles, water, land, food security, and climate change in SSA. Sub-Saharan Africa is geographically located south of the Sahara Desert. The region encompasses diverse landforms, climate, and people. For example, the region comprises an arid Type B climate in the Northern zone and tropical Type A climate in the Southern zone. The arid Type B climate also resurfaces in the Southern latitudes around the Namib and Kalahari Deserts. Natural phenomena such as climate change exacerbated by human activity such are overgrazing and land-use practices have further increased the pressure on the already vulnerable region resulting in the spread of the desert. In specific areas in the Southern part of Africa, larger farming operations exist in type $\mathrm{C}$ climates. In the central part of the continent, around the equator, Tropical Type A climate prevails characterized by abundant yearly rainfall and volcanic soils favorable for agriculture. Noteworthy is that the geography of this region differs from one country to the other. Subsistence agriculture, for example, is the backbone of the region with about $70 \%$ of the population engaged in Agriculture (Hellmuth et al., 2007). Natural resources are another source of livelihood and wellbeing of a larger part of the SSA population. However, these resources have been over-exploited due to increasing demands, changes in consumption patterns, rising population among others leading to their degradation.

This desk study is based on a systematic review of relevant literature. The first phase of the study involved purposive selection for the study to come up with a reasonable conclusion. A wide and systematic internet search on databases of indexed journals and other peer-reviewed publications such as Google Scholar, Science Direct, and Scopus. Keywords like gender roles, water-land-energy-food security nexus, and climate change were inserted in the search engine using a four-stage process (see Figure 1). This effort provided 375 peer-reviewed articles which had information relating to the scope of the study.

Out of these articles, approximately 47 articles and reports were sampled because they described presumably recent knowledge in this twenty-first century to form the contextual and theoretical framework of this study. Using a deviant case 


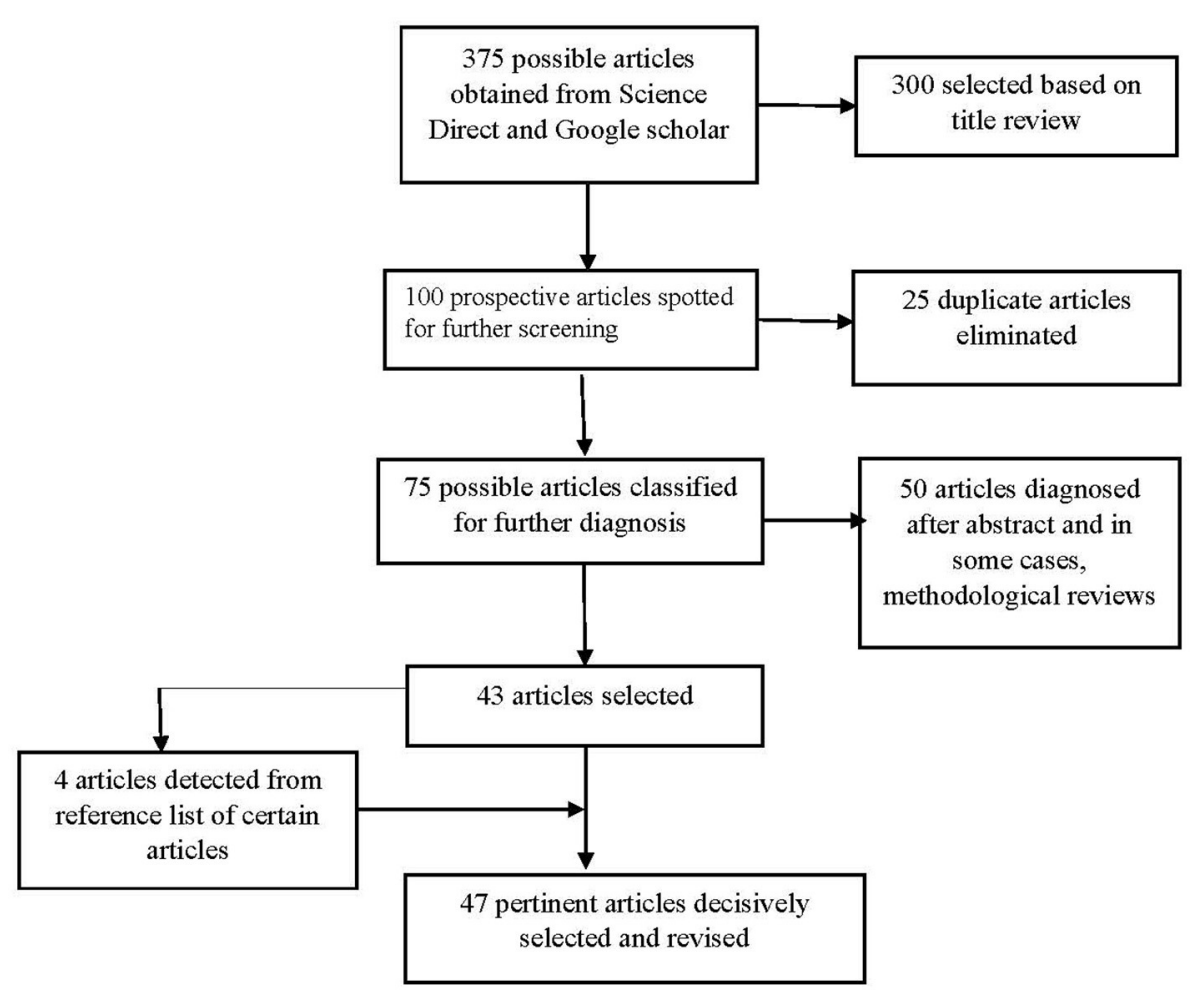

FIGURE 1 | Flow diagram showing the different phases of selecting relevant literature.

sampling ${ }^{1}$, around 47 scholarly articles published between 1998 and 2020 (33 from sub-Sahara Africa and 14 from other developing countries) were purposefully selected to form the basis for the study. Building on the choice of the selected papers, 04 publications on water-energy-food security nexus in South Africa; 05 on WLF security nexus in East Africa; 10 on gender roles and food security in West and Central Africa, 04 on climate change in South Africa; 07 on policy implications on access and ownership of land in SSA; 04 on water-energy-land-food security nexus in the Caribbean and India; and 04 on gender roles and climate change in South America and India were selected to represent the approaches and practices in other developing countries for comparability. The remainder were publications (UNDP, IPCC reports) cut across many countries, regions, and continents. Publications on the WLF nexus in SSA was given priority because they are mostly used as a benchmark for other developing countries by international organizations.

\section{ANALYSIS AND DISCUSSION \\ WLF and the Impact of Climate Change and Adaptation}

Human beings are the principal factor in molding the natural environment. Increasing population, urbanization, and

\footnotetext{
${ }^{1} \mathrm{~A}$ deviant sampling is a process of selecting outstanding successful cases or those with remarkable failures. This helps to learn lessons that are relevant to improving other studies.
}

increasing standards of living have coincided with the increasing demand for food, for example, to put more strain on natural resources (Tantoh and McKay, 2020). This has been exacerbated as the effects of climate change continue to add to the problems since many climate change mitigation and adaptation strategies such as irrigation, desalination of seawater are resource sensitive (Wichelns, 2018). To attain sustainable development in SSA, where there is a great reliance on the natural environment, precedence responsiveness toward WLF is crucial. The WLF nexus concept has thus, attracted attention from diverse sectors including academics, industry, policy, and diplomacy. The nexus embraces the idea that water, land, and food security are intricately interrelated [The Intergovernmental Panel on Climate Change (IPCC), 2019]. However, this interrelation is expected to intensify between these resources and the probable negative effects will have serious constraints to sustainability (Rasul and Sharma, 2016). This is because current demands and natural resource use threaten to undermine the breadth and sustainability of development. It is further argued that the effect in a sector will definitely influence the functioning of others (Wichelns, 2018). This call for an integration of related resources such as water, land, and food production in the management. Integrated solutions are therefore needed to steer the elaboration and execution of SDGs (see Figure 2).

The WLF nexus approach informs the evolving national green economy roadmaps to ensure effectiveness in national development programs, particularly in SSA countries. Correspondingly, the WLF nexus sought to identify the 


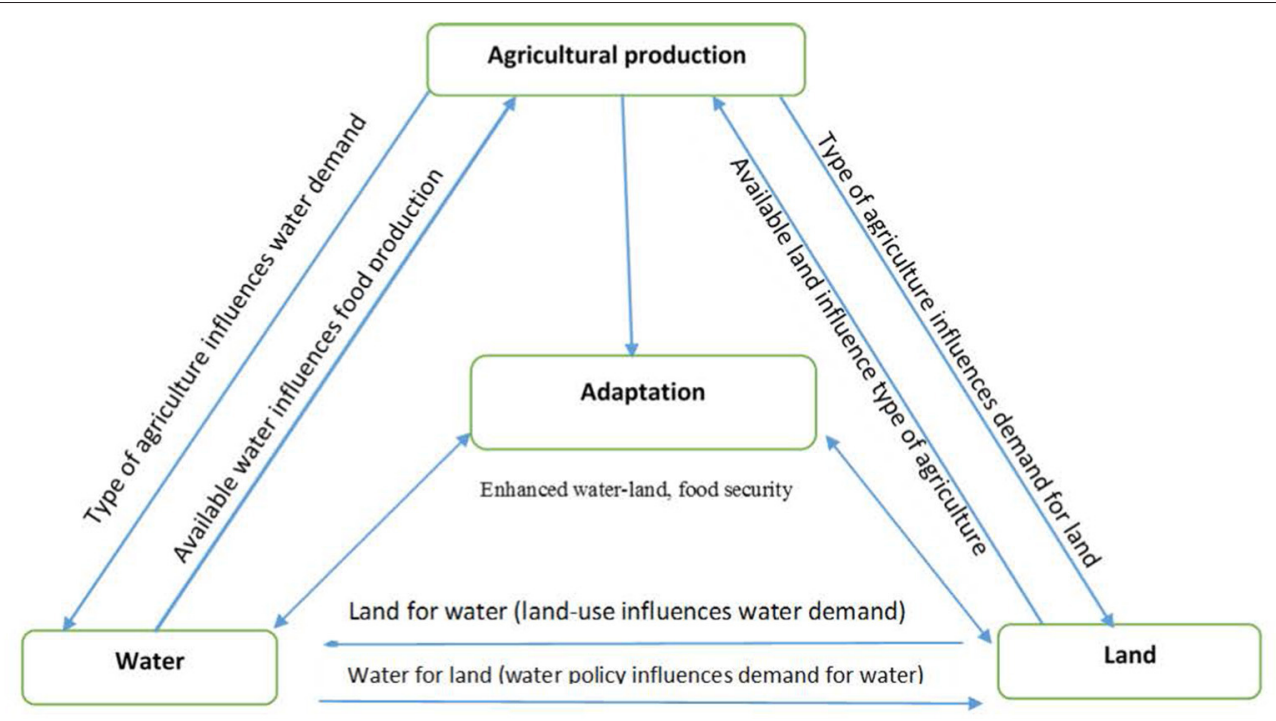

FIGURE 2 | The interface between water, land, and food adaptation.

synergies and interlinkages between these components, which were previously considered separately (Mahlknecht et al., 2020). Given that SSA, for example, is among the most dynamic and vulnerable regions of the world, the demand, and exploitation of natural resources are huge. Rising population and changes in land-use patterns have intensified the pressure on land, water, and food security coupled with the climate crisis resulting in environmental degradation (see Figure 2). This is in line with the findings of the Intergovernmental Panel on Climate Change [The Intergovernmental Panel on Climate Change (IPCC), 2019], for example, which highlighted that about $46 \%$ of Africa's land experiences degradation and this affects roughly 485 million. This has resulted in serious implications in the adaptation strategies, particularly in rural communities where most of the poor reside. Water, for example, is indispensable for livelihoods and wellbeing, for irrigated agriculture and food production. This is especially true with respect to agriculture which uses approximately $70 \%$ of water resources (AfDB, 2011). This increasing population need enough food for sustenance coupled with competing uses resulting in modification of dietary choices toward beef and additional energy-demanding foodstuffs. This increases the demand for and use of water and land. In the same vein, the improvement of agricultural practice and land-use changes can possibly result in a reduction in production possibilities (Sakho-Jimbira and Hathie, 2020). This has been aggravated by the climate crisis which is expected to adversely affect food production and possibly worsen undernourishment.

An understanding of the connection between WLF resources can promote comprehensive inter-sectoral decision-making and ensure sustainability (Howells et al., 2013). This is because WLF is fundamental to development despite the climate crisis. Furthermore, water is crucial in the functioning of the system. Noteworthy is that the relationship between these systems goes beyond the water footprint, carbon-footprint water supply chains or analyzing new food security sources in relation to water consumption and/or its impact on land, and food security.
At the center of the relationship is the interdependence of resources. For example, the demand for one can drive the demand for another and similarly how the cost of one can influence the efficiency of production of the other (Gulati et al., 2012). Within SSA, rural communities, coastal, and low-lying regions are particularly vulnerable to the effects of climate change, with the bulk of the population, mostly women ever more subjected to growing physical, social, and economic threats against the impending challenges in water, land, and food security (UNDP, 2010; Namubiru-Mwaura, 2014). This is further intensified by the lack of access to land which is a major capital of production for rural women in particular. It is worth mentioning that the notion of security transcends access to interrelated resources (Biggs et al., 2015). This is because of the inability to access and use these resources coupled with socio-cultural flux and power relations that influence the use and management of these resources (Biggs et al., 2015).

\section{Gender Roles in WLF and Implications to the Effect of Climate Change}

Rural women in SSA, for example, face diverse constraints to the access and management of natural resources. Women, for example, represent over $60 \%$ of the farm workforce in West and Central Africa but have inadequate access to land, technology, and financial resources [International Fund for Agricultural Development (IFAD), 2019]. They are further marginalized when it comes to access, ownership of land, and the management of natural resources, preventing them from adequately realizing their livelihoods and wellbeing (Fonjong, 2008). Gender inequality is, for example, evident in SSA and some parts of Asia (Namubiru-Mwaura, 2014). It is generally assumed that women face discrimination and disadvantages on top of those faced by men due to unequal gender relations (Mikkelsen, 2005). However, women appear to easily access land in Eastern and Southern Africa than in any other part of 
Africa (UN 2010). This disparity amongst women, for example, shows that women make up only $20 \%$ of landholders and their limited access to land is common in countries and communities with diverse socio-cultural and economic background (Food and Agriculture Organization, 2010). Paradoxically, women play significant roles in the private sector, although they mostly focused on agriculture, buying and selling of agricultural products (Hedditch and Manuel, 2010). A gender dimension in natural resource management shows that gender roles are decisive in natural resource management although with differing effects on men and women (Mikkelsen, 2005). In Cameroon, for example, women perform different roles and have different interests and stakes (Fonjong, 2008). However, they are exposed to more restrictions and inadequacies. They are further mostly exposed to the effects of climate change more than men (Nzomo, 1992; AfDB, 2011). This is because the effects of climate change are directly related to their sources of livelihoods. The impacts of climate change have further strengthened pre-existing gender disparities principally those related to household food security and nutritional wellbeing. Given that the effects of climate change are severe on women, the risks faced by handicapped women are multiple because of their physical inabilities and also because they depend on natural resources most at risk to the effects of climate change for their livelihoods and wellbeing [International Fund for Agricultural Development (IFAD), 2019; International labour organization (ILO), 2019]. This greatly affects their agricultural production potential.

Moreover, approaches to sustainable development and management of environmental resources have focused on "top-down" tendencies (Fonjong, 2018; Musavengane et al., 2019). This is strengthened by the patriarchal culture, leadership, decision-making, and resource management which historically and traditionally rests in the hands of traditional authorities and older men and male household heads (Tantoh and McKay, 2020). Consequently, local decision-making and control over resources reside with male members of society, strengthening gender imbalances, and propagating the suppression of individual rights. This is further aggravated by inadequate political will and commitment by both the central government and the local authorities to challenge patriarchal norms and privilege at the local level, such as prejudiced gendered community obligations (Moyo, 2014; Chant, 2016). In contrast, bottom-up approaches to management have proven to ensure sustainable livelihood particularly, in rural communities (Tantoh and Simatele, 2018), participative, collaborative/comanagement of resources (Musavengane et al., 2019) between men, women, private, public stakeholders at the community, local, and national levels. There has, therefore, been a shift in perspectives on participation and sustainable livelihood strategies with the involvement of all resource users, especially those in close proximity (Tantoh and Simatele, 2018). This has been further reinforced by development aid organization such as the United Nations advocating the involvement of women in any development project. Women now occupy decision-making positions in several works of life in many developing countries.

\section{The Promise of a Gender-Oriented Based Approach for Sustainability}

The adaptation strategies in some sector can possibly offer a synergic win-win opportunity to improve alleviation and adaptation in several other sectors. In the context of this study, for example, water and land are essential for food security and poverty alleviation. Thus, advancing the adaptability of freshwater has the possibility to influence several other sectors, as it improves availability and accessibility of water for farming, and industry and in that way reduce emissions. Considering that women are crucial in the use and control of natural resources (Fonjong, 2008), they should be involved in decisionmaking processes in the management. This is because women are responsible for providing potable water for domestic use, fuelwood for cooking, and heating in many SSA countries. This put them at the center of the water-land, and food security nexus. Furthermore, access to water and land by women, in particular, is vital for poverty alleviation and reduction of vulnerability (Moyo, 2014; Villamor et al., 2018). However, the role of women in the WLF interconnection in dealing with the increasing demands of natural resources and enabling adaptation is in spite of everything being effusively acknowledged. In view of the multifaceted relationship of WLF supply and demand, several possibilities, and difficulties will prevail to reduce trade-offs (Howells et al., 2013; Biggs et al., 2015). This will encourage partnership to create operative adaptation opportunities. Thus, an understanding of the connection of water, land, and food security nexus and gender-oriented based approach are essential for planning diverse adaptation strategies and sustainability. Furthermore, understanding the synergies and trade-offs in the WLF nexus can offer innovative insights for effective approaches to adaptation. Noteworthy is that recent social changes have compelled the national governments in most of SSA to embark on land policy reforms. Since access and ownership of land by women, in particular, is fundamental for the reduction of poverty alleviation and sustainable development, land reforms are inevitable (Toulmin and Quan, 2000; Ubink and Quan, 2008).

\section{CONCLUSION}

This systematic review examines gender roles and their implications for water, land, and food security nexus in a changing climate. Current trends require responsiveness for water, land, and food safety to achieve sustainability in regions solely reliant on natural resources. The analysis illustrates that water and land are vital resources essential to ensure sustainable and productive rural economies. They are also essential for ensuring food security and socio-economic development. Still, the notion of WLF security nexus is mostly managed from a top-down, centralized approach with women mostly excluded in the access, ownership, and management of water and land in particular. Their inadequate access to resources, constrained formal rights through top-down, and centralized management tendencies intensifies their vulnerability. In most cases, however, customary norms restrict the ownership and control of land by rural women. This is common in communities with patrilineal 
cultures. This gender neglect in land and other natural resources has eventuated persistent disputes between resource users and managers. Inadequate access to land and secure tenure is repeatedly emphasized as one of the leading causes of the vulnerability of women (Namubiru-Mwaura, 2014; Villamor et al., 2018). In the same vein, women are mostly exposed to the effects of climate change and this reinforces gender disparities. This, also, directly and indirectly, limits their stewardship of natural resources and mitigation of the effects of climate change. However, they are important vehicles of development and must be involved in the management to optimize their benefits. This is because women's participation in natural resource management is fundamental for women's empowerment are a precondition for ensuring safe, sound, and resilient societies. Access to

\section{REFERENCES}

Abulibdeh, A., Zaidan, E., and Al-Saidi, M. (2019). Development drivers of the water-energy-food nexus in the Gulf Cooperation Council region. Dev. Pract. 29, 582-593. doi: 10.1080/09614524.2019.1602109

AfDB (2011). Climate Change, Gender and Development in Africa. Available online at: https://www.afdb.org/sites/default/files/documents/publications/climate_ change_gender_and_development_in_africa.pdf (accessed March 25, 2021).

Agarwal, B. (2003). Gender and land rights revisited: exploring new prospects via the state, family and market. J. Agrar. Change 3, 184-224. doi: 10.1111/1471-0366.00054

Biggs, E. M., Bruce, E., Boruff, B., Duncan, J. M. A., Horsley, J., Pauli, N., et al. (2015). Sustainable development and the water-energy-food nexus: a perspective on livelihoods. Environ. Sci. Policy 54, 389-397. doi: 10.1016/j.envsci.2015.08.002

Chant, S. (2016). Women, girls and world poverty: empowerment, equality or essentialism. Int. Dev. Plann. Rev. 38, 1-24. doi: 10.3828/idpr.2016.1

Cotula, L. (2007). Legal Empowerment for Local Resource Control: Securing Local Resource Rights Within Foreign Investment Projects in Africa. 12542IIED.

Donkor, F. K., Mearns, K., Ojong, E., Tantoh, H. B., Ebhuoma, E., Hadisu, A., et al. (2020). "Attitudinal changes towards agriculture through the generational lens and impact on engagement in related activities: case study from a mountainous area," in Food Security and Land Use Change Under Conditions of Climate Variability, eds V. Squires and M. Gaur (Cham: Springer), 165-179.

Ebhuoma, E., Simatele, M., Tantoh, H. B., and Donkor, F. (2019). Asset vulnerability analytical framework and systems thinking as a twin methodology for highlighting factors that undermine efficient food production. Jàmbá 11:597. doi: 10.4102/jamba.v11i1.597

FAO (2011). Climate Change, Water and Food Security. FAO Water Reports No. 36. Rome: Food and Agriculture Organization of the United Nations.

FAO (2014). The Water-Energy-Food Nexus. A New Approach in Support of Food Security and Sustainable Agriculture. Rome: Food and Agriculture Organization of the United Nations.

Fonjong, L. N. (2008). Gender roles and practices in natural resource management in the North West Province of Cameroon. Local Environ. 13, 461-475. doi: 10.1080/13549830701809809

Food and Agricultural Organisation (FAO) (2013). The Water-Energy-Food Nexus A New Approach in Support of Food Security and Sustainable Agriculture. Rome: Food and Agriculture Organization of the United Nations.

Food and Agriculture Organization (2010). Gender Dimensions of Agricultural and Rural Employment: Differentiated Pathways out of Poverty. Status, Trends and Gaps. Rome: FAO.

Gulati, M., Jacobs, I., Jooste, A., Naidoo, D., and Fakir, S. (2012). The water-energyfood security nexus: challenge and opportunities for food security in South Africa. Aquat. Proc. 1, 150-164. doi: 10.1016/j.aqpro.2013.07.013

Hedditch, S., and Manuel, C. (2010). Gender and Investment Climate Reform Assessment: Pacific Regional Executive Summary. Washington, DC: and ownership of land by women can be a potential for transformation and a way of obtaining extra possessions thereby involving in several socio-economic activities. There is a need to fully incorporate women in the design and management of natural resources in general which will empower and give them a sense of belonging.

\section{AUTHOR CONTRIBUTIONS}

HT: conceptualization, visualization, design of research instruments, and writing-original draft. TM, FD, and MS: writing-review and editing and supervision. All authors have read and agreed to the published version of the manuscript.

International Finance Corporation. World Bank. Available online at: https:// openknowledge.worldbank.org/handle/10986/20189 (accessed May 15, 2021).

Hellmuth, M. E., Moorhead, A., Thomson, M. C., and Williams, J. (eds.). (2007). Climate Risk Management in Africa: Learning from Practice. New York, NY: International Research Institute for Climate and Society (IRI).

Hoff, H. (2011). "Understanding the nexus," Background Paper for the Bonn 2011 Conference: The Water, Energy and Food Security Nexus (Stockholm: Stockholm Environment Institute (SEI)).

Howells, M., Hermann, S., Welsch, M., Bazilian, M., Segerstrom, R., Alfstad, R., et al. (2013). Integrated analysis of climate change, land-use, energy and water strategies. Nat. Clim. Change 3, 621-626. doi: 10.1038/ nclimate 1789

International Fund for Agricultural Development (IFAD) (2019). The West and Central Africa Advantage. Fighting Fragility for Smallholder Resilience., Rome: International Fund for Agricultural Development. Available online at: www.ifad.org (accessed April 25, 2021).

International labour organization (ILO) (2019). Indigenous Peoples and Climate Change: Emerging Research on Traditional Knowledge and Livelihoods Gender. Geneva: Gender, Equality and Diversity \& ILOAIDS Branch.

IPCC (2008). IPCC Fourth Assessment Report: Climate Change 2007. Available online at: http://www.ipcc.ch/site/assets/uploads/2018/03/ar4_wg2_full_ report.pdf (accessed February 2021).

Kenjio, J. W. K. (2020). Decolonizing land tenure systems in Sub-Saharan Africa: the path to modern land policy reforms. J. Land Manage. Appr. 7, 1-9. doi: 10.5897/JLMA2020.0017

Lawford, R., Bogardi, J., Marx, S., Jain, S., Pahl Wostl, C., and Knuppe, K., et al. (2013). Basin perspectives on the water-energy-food security nexus. Curr. Opin. Environ. Sustain. 5, 607-616. doi: 10.1016/j.cosust.2013.11.005

Lendevlo, S., Munyebvu, F., and Suich, H. (2012). Linking women's participation and benefits within the Namibian community based natural resource management program. J. Sustain. Dev. 5, 1-13. doi: 10.5539/jsd.v5n12p27

Mahlknecht, J., Gonzalez-Bravo, R., and Loge, F. J. (2020). Water-energy-food security: a Nexus perspective of the current situation in Latin America and the Caribbean. Energy 194:116824. doi: 10.1016/j.energy.2019.116824

Michael, B. P. (1998). The role of women in water resources management: the Tanzania case. Int. J. Water Resour. Dev. 14, 499-504. doi: 10.1080/07900629849123

Mikkelsen, C. (2005). Indigenous Peoples, Gender, And Natural Resource Management. DIIS Working Paper No. 2005/5. Available online at: https:// www.econstor.eu/handle/10419/84605 (accessed June 20, 2021).

Moyo, C. S. (2014). Active participation of rural women in developmental issues: poverty alleviation lessons for South Africa. Gender Behav. 12, 5994-6001. https://doi:10.10520/EJC154679

Musavengane, R., Tantoh, H. B., and Simatele, D. M. (2019). A comparative analysis of collaborative environmental management of natural resources in sub-Saharan Africa: a study of Cameroon and South Africa. J. Asian Afric. Stud. 54(4): 512-532. doi: 10.1177/0021909618825276 
Namubiru-Mwaura, E. (2014). Land Tenure and Gender: Approaches and Challenges for Strengthening Rural Women's Land Rights. Washington, DC: World Bank. Available online at: https://openknowledge.worldbank.org/ handle/10986/21033 (accessed May 10, 2021).

Njoh, A. J. (2013). Equity, fairness and justice implications of land tenure formalization in cameroon: equity of land tenure formalization in Cameroon. Int. J. Urban Region. Res. 37, 750-768. doi: 10.1111/j.1468-2427.2012.01168.x

Nzomo, M. (1992). "Policy impacts on women and environment," in Groundwork: African Women as Environmental Managers, ed S. A. Khasiani (Nairobi: African Center for Technology Studies), 101-117.

Quisumbing, A., Rubin, D., Manfre, C., Waithanji, E., van den Bold, M., Olney, D., et al. (2015). Gender, assets, and market-oriented agriculture: learning from high-value crop and livestock projects in Africa and Asia. Agric. Hum. Values 32, 705-725. doi: 10.1007/s10460-015-9587-x

Rasul, G., and Sharma, B. (2016). The nexus approach to water-energy-food security: an option for adaptation to climate change. Clim. Pol. 16, 682-702. doi: 10.1080/14693062.2015.1029865

Ringler, C., Bhaduri, A., and Lawford, R. (2013). The nexus across water, energy, land and food (WELF): potential for improved resource use efficiency? Curr. Opin. Environ. Sustain. 5, 617-624. doi: 10.1016/j.cosust.2013.11.002

Sakho-Jimbira, S., and Hathie, I. (2020). The Future of Agriculture in Sub-Saharan Africa. Policy Brief No. 2 April 2020. Available online at: https://www.ifad.org/ documents/38714170/42030191/future_agriculture_sahara_e.pdf/1cb6b896b9c1 (accessed April 26, 2021).

State of the Planet Declaration (2012). Planet Under Pressure: New Knowledge Towards Solutions. London: Organised by the global change research programmes of the International Council for Science.

Tantoh, H. B., and McKay, T. J. M. (2018). Rural self-empowerment: the case of small water supply management in Northwest, Cameroon. Geo J. 85, 159-171. doi: 10.1007/s10708-018-9952-6

Tantoh, H. B., and McKay, T. J. M. (2020). Investigating community constructed rural water systems in Northwest Cameroon: leadership, gender and exclusion. Int. Dev. Plann. Rev. 42, 455-478. doi: 10.3828/idpr.2020.4

Tantoh, H. B., and Simatele, D. (2018) Complexity and uncertainty in water resource governance in Northwest Cameroon: reconnoitring the challenges and potential of community- based water resource management. Land Use Policy 75, 237-251. doi: 10.1016/j.landusepol.2018.03.044

Tantoh, H. B., Simatele, M. D., Ebhuoma, E. E., Donker, F., and McKay T. J. M. (2019). Towards a pro-community-based water resource management system in Northwest Cameroon: practical evidence and lessons of best practices. GeoJournal. doi: 10.1007/s10708-019-10085-3

The Intergovernmental Panel on Climate Change (IPCC) (2019). An IPCC Special Report on Climate Change and Land: What's in it for Africa? Climate and Development Knowledge Network. The Intergovernmental Panel on Climate Change (IPCC) Available online at: https://reliefweb.int/report/world/ipcc-sspecial-report-climate-change-and-land-what-s-it-africa (accessed April 26, 2021).

The Intergovernmental Panel on Climate Change (IPCC) (2018). "Summary for policymakers," in Global Warming of $1.5^{\circ} \mathrm{C}$, An IPCC Special Report on the Impacts of Global Warming of $1.5^{\circ} \mathrm{C}$ Above Pre-industrial Levels and Related Global Greenhouse Gas Emission Pathways, in the Context of Strengthening the Global Response to the Threat of Climate Change, Sustainable Development, and Efforts to Eradicate Poverty, eds V. Masson-Delmotte, P. Zhai, and H.O. Portner et al. (Geneva: World Meteorological Organization).
Tiondi, E. (2000). Women, Environment and Development: Sub-Saharan Africa and Latin America. Graduate Theses and Dissertations. Available online at: https:// scholarcommons.usf.edu/etd/1549 (accessed March 5, 2021).

Toulmin, C., and Quan, J. (eds.). (2000). Evolving Land Rights, Policy and Tenure in Africa. Available online at: https://pubs.iied.org/7416iied (accessed June 10, 2021).

Ubink, J. M. (2008) In the Land of the Chiefs Customary Law, Land Conflicts, and the Role of the State in Peri-Urban Ghana. Leiden: Leiden University Press. doi: 10.5117/9789087280413

Ubink, J. M., and Quan, J. M. (2008). How to combine tradition and modernity? Regulating customary land management in Ghana. Land Use Policy 25,198-213. doi: 10.1016/j.landusepol.2007.06.002

UN ECOSOC (1997). Coordination of the Policies and Activities of the Specialized Agencies and Other Bodies of the United Nations System. Substantive session of 1997 Geneva. Available online at: http://www.un.org/esa/documents/ecosoc/ docs/1997/e1997-66.htm (consulted April 10, 2021)

UNDP (2008). UNDP Gender Equality Strategy 2008-2011. New York: United Nations Development Programme (UNDP). Available online at: http://www. iknowpolitics.org/en/knowledge-library/report-white-paper/empoweredand-equal-gender-e (accessed March 5, 2021).

UNDP (2010). Gender, Climate Change and Community-Based Adaptation: A Guidebook for Designing and Implementing Gender-Sensitive Community-Based Adaptation Programmes and Projects. New York: United Nations Development Programme (UNDP).

Villamor, G. B., Guta, D., Djanibekov, U., and Mirzabaev, A. (2018). Gender Specific Perspectives Among Smallholder Farm Households on Water-EnergyFood Security Nexus Issues in Ethiopia, ZEF - Discussion Papers on Development Policy No. 258, Center for Development Research, Bonn. p. 32. doi: 10.2139/ssrn.3180530

Wichelns, D. (2018). The Water-Energy-Food Nexus: is the increasing attention warranted, from either a research or policy perspective? Environ Sci Policy 69:113e23. doi: 10.1016/j.envsci.2016.12.018

World Economic Forum (2011). Water Security: The Water-Food-Energy-Climate Nexus. World Economic Forum (WEF), Washington DC.

Conflict of Interest: The authors declare that the research was conducted in the absence of any commercial or financial relationships that could be construed as a potential conflict of interest.

Publisher's Note: All claims expressed in this article are solely those of the authors and do not necessarily represent those of their affiliated organizations, or those of the publisher, the editors and the reviewers. Any product that may be evaluated in this article, or claim that may be made by its manufacturer, is not guaranteed or endorsed by the publisher.

Copyright $\odot 2021$ Tantoh, McKay, Donkor and Simatele. This is an open-access article distributed under the terms of the Creative Commons Attribution License (CC $B Y)$. The use, distribution or reproduction in other forums is permitted, provided the original author(s) and the copyright owner(s) are credited and that the original publication in this journal is cited, in accordance with accepted academic practice. No use, distribution or reproduction is permitted which does not comply with these terms. 